\title{
Tourism and the COVID-19 Global Pandemic - Analysis of Opinions of Czech and Slovak Tourism Students
}

\author{
Jiři Vaníček ${ }^{1, *}$, Anna Šenková2 ${ }^{2}$, and Liběna Jarolímková ${ }^{1}$ \\ ${ }^{1}$ University of Economics, Prague, Faculty of International Relations, Department of Tourism, W. \\ Churchill sq. 4, 13067 Prague, Czech Republic \\ ${ }^{2}$ University of Prešov in Prešov, Faculty of Management, Department of Tourism and Hotel \\ Management, Konštantínova 16, 08001 Prešov, Slovak Republic
}

\begin{abstract}
.
Research background: Coronavirus has hit universities on several levels, from interrupting teaching and returning students home and changing the form of teaching. Universities have switched to online teaching. The Universities in Prague and Prešov have agreed to use this situation to ascertain students' views on the course of teaching during a pandemic and their opinions on the further development of tourism at home and in the world.

Purpose of the article: The main purpose of the research was to examine the views of tourism students on current events in tourism from a global and local perspective and to compare the views of Czech and Slovak students.

Methods: Both universities conducted an online questionnaire survey among tourism students. The questionnaire had two parts: students' opinions on online teaching during the corona crisis and opinions on the further development of tourism in their countries and in the world after the COVID19 pandemic.

Findings \& Value added: The results of the survey brought interesting findings. The COVID-19 pandemic had a negative impact on students' lives, for example, lost their work while studying, cancel trips at home and abroad, including studies at foreign universities. Despite that, most students see their future in tourism. Students expect an increase in domestic tourism this year, a decrease in outgoing and incoming. They expect this trend in the next few years as well. Opinions on the development of tourism in the world are in line with the opinion on the development of national tourism.
\end{abstract}

Keywords: COVID-19; online teaching; students of tourism; survey; the future development of tourism.

JEL Classification: Z30; Z32; Z33; Z38.

* Corresponding author: jiri.vanicek@,vse.cz 


\section{Introduction}

The COVID-19 outbreak is a sharp reminder that pandemics, like other rarely occurring catastrophes, have happened in the past and will continue to happen in the future. The current outbreak has had severe economic consequences across the globe, and it does not look like any country will be unaffected [1]. "The current crisis also offers many research opportunities to learn from the crisis and tailor future business processes. Corona crisis has exposed and laid bare the at-time neglected and sometimes hidden interdependence between business and society" [2]. Many economic activities have more or less come to a standstill since measures were taken against the spread of SARS-CoV-2. The COVID-19 pandemic is the most severe global crisis since WWII. COVID-19 restrictions have effectively stopped economies around the world and the global economy is expected to enter a recession in 2020. [3]. State borders were closed, travelling was strongly limited, accommodation services have been stopped and boarding was also strong limited. International and home transport was cancelled or strongly limited, all conferences, sports, cultural and company events were cancelled. Unquestionable, the coronavirus (COVID-19) pandemic is undoubtedly one of the most significant events of the 21 st century and has huge impact on tourism [4]. Tourism is therefore currently one of the most affected sectors [5]. International tourism has serious consequences for the COVID19 outbreak, especially for major tourism destinations such as France, Italy, and Spain as well as for countries with high volumes of outgoing tourism such as China and the United States [6]. Forecasting the future development of the section is very difficult. According to UNWTO the introduction of travel restrictions led to a fall in international tourist arrivals: $55 \%$ decline in March, and 97\% in April 2020 [7]. This decline would put 100 to 120 million direct tourism jobs at risk [8]. While rapid recovery is expected in 2021; 2019 volumes of international travel are not expected to be regained until 2023 [9]. COVID-19 provides striking lessons to the tourism industry, policy makers and tourism researchers about the effects of global change. The challenge is now to collectively learn from this global tragedy to accelerate the transformation of sustainable tourism [10. Current statistics (the first quarter of 2020) in the Czech and Slovak Republics demonstrate considerable failure of output in tourism industry caused by limited accommodation and boarding services since the middle of March 2020. During the period January - March 2020 the decline of accommodation services reached $22 \%$, in April $97 \%$ [11], [12]. The effects of anti-epidemic measures affect all sections of the population. The global higher education environment has dramatically changed in the past few months due to the spread of the coronavirus [13]. Almost all schools worldwide had to stop face-to-face education and started online teaching. As a segment within wider society, students are hit in multiple ways [14]. Students across the higher education sector have been dramatically impacted from travel restrictions to social distancing, isolation measures, quarantines, campus closures, loss of additional earnings and border closures [13]. For universities and schools forced to close, buffering included the rapid substitution of classroom-based teaching by online teaching. In the future, new approaches to teaching will emerge, all academics will have to alter the ways in which they facilitate learning outcomes [15]. The results of the research which have been recently published demonstrate strong impact on undergraduates, great number of them are strongly affected by the situation: $40-46 \%$ of them change their study plans (most often extension the time of study). Exchange students have been most effected, $70-85 \%$ cancel or put off their foreign travel. The next $61-68 \%$ are afraid of financial problems as a result of decreasing family savings [13], [16], [17]. Although universities realised online teaching in the summer semester, great number of foreign students $(61 \%)$ do not intend to go on studying in the future [13]. There are several critical factors associated with online teaching. Online students face a heightened risk of feeling isolated more so when they can't meet due to COVID-19 social distancing rules. Students in online-learning environments may not learn at the same 
pace as students in physical teaching and learning settings. Educators need to adjust expectations about progression and provide timely constructive feedback when the pace slows down [18]. The impact of the COVID-19 pandemic on education has quickly become the subject of further research around the world [19], [20], [21]. Nevertheless, we are only at the earliest of beginnings of recognising and understanding these impacts on the role of academics and the future of global higher education [22]. The students of tourism at University of Economics in Prague and University of Prešov in Prešov have experienced multiple effect of COVID-19 restrictions. Since March 2020 regular studying have been closed. University of Economics in Prague and Prešov University in Prešov were the first universities that switched to distant forms of teaching (since 10. March 2020). All of a sudden, the life of students changed abruptly. Thanks to the internet, various forms of teaching emerged and enabled addressed communication. Travel restriction all over the world effected personal and study plans of many students studying tourism. Those students belong to the most effective members of foreign mobility. Most of the students finished their stay abroad and concluded the study in distant form. Neither teachers nor students had any experience in online teaching of such a great extend. The implemented research emerged to obtain a quick feedback of online teaching. The research also included finding out the student's views on the perspective of tourism because tourism is experiencing a bad crisis at present. This fact can the students' decision in planning their future career.

\section{Methods}

The purpose of this article is to present the results of the research focused on perception of positive and negative sides of distant forms of studying during the pandemic and on further development of tourism in the Czech Republic and in Slovakia in 2020 and further on. The research was carried out by identical methodology at the Department of Tourism University of Economics in Prague and Department of Tourism and Hotel Management University of Prešov in Prešov. All the students of all years of bachelor and master studies participated in the research. The questionnaire consisted of two parts. The first part found out the students' view on online studying in the summer semester 2020. The second part was focused on students' opinion of further development of tourism at home and in the world after the COVID-19 pandemic. 200 students of both universities took part in the research. Before the research started a pilot research, was carried out by approximately 10 students and based on their answers and mainly of their remarks the questionnaire was finalized. Obtaining primary data by the questionnaire was carried out by means of application Office 365 Microsoft Forms in May 2020. As there are more female students than male students at the Department of Tourism at both universities, the proportion of gender was approximately 80:20. The presented figures show relative part of students (\%) that agreed with the given statement.

\section{Results and Discussions}

\subsection{Opinions of students of tourism on online learning}

The first question was as follows: "What effect did the coronavirus pandemic have on your activities in the summer semester?" As the students' answer from both schools did not differ much, the stated structure of all the answers is common (Fig. 1). Almost half of the students lost their jobs that they did in addition to their studies. $31 \%$ of the students canceled their travel abroad. A quarter of the students canceled home travel, $22 \%$ submitted quarantine and every $14^{\text {th }}$ student did a voluntary work, mostly making face masks and distributing them to senior people. 


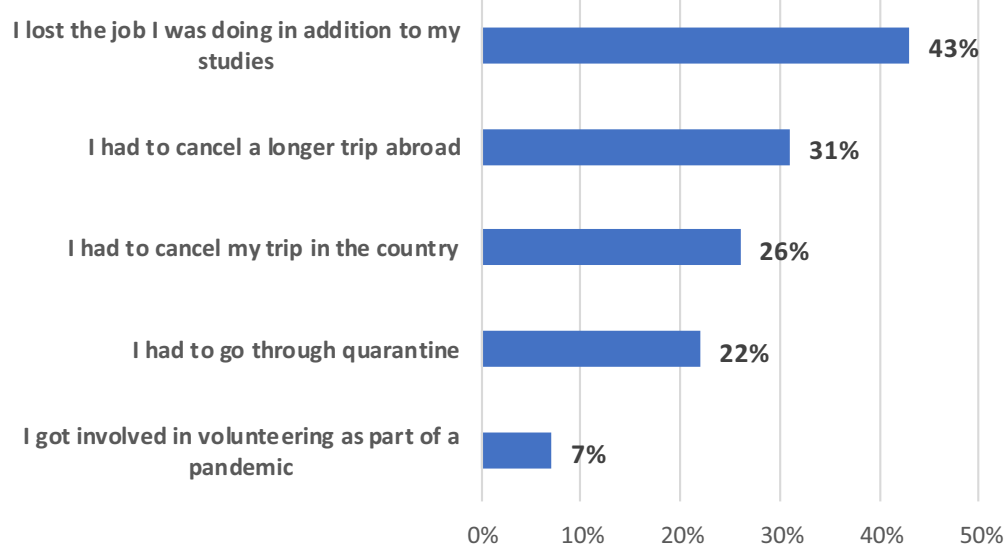

Fig. 1. What effect did the coronavirus pandemic have on your activities in the summer semester?

The next question asked how convenient the switch to online teaching was. We bring forward the results from both schools (Fig. 2). The answers stated that half of the students think they learn less although they spend more time on learning. $60 \%$ of the students feel higher claims on technical providing online connection. 8 out of 10 students realise that online teaching place higher demands from the point of view of independent work.

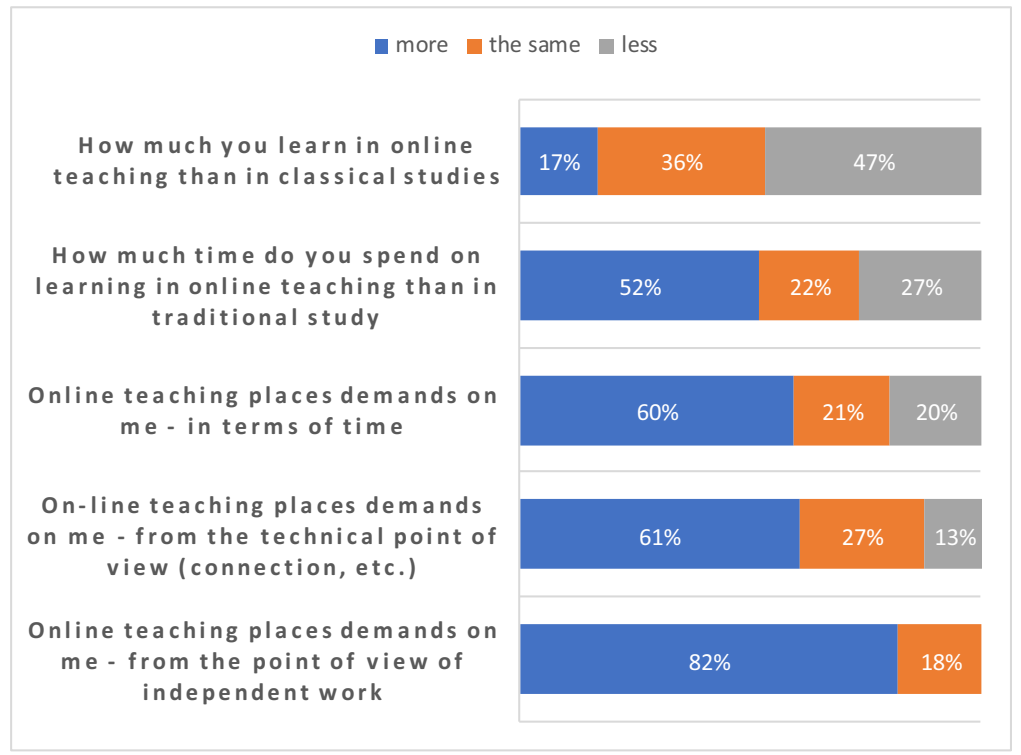

Fig. 2. What is your experience with online learning? (proportion of positive answers)

The next one logically follows the previous question: "What is your experience with online learning?" While $55 \%$ of respondents would welcome higher proportion of online studying, $45 \%$ of them reject applying online learning under regular standard circumstances. It is interesting that the number of answers "yes" and "no" is identical for Czech and Slovak students (yes $-55 \%$, no $-45 \%$ ). We achieved the following most often repeated answers: 1. A teacher does not explain the problem in detail in online teaching.

2. Online teaching is not full-fledged. 
3. Online teaching is convenient for me to some extend, but I prefer personal contact.

4. Online teaching is not satisfying in language teaching.

5. Most teachers do it on basis level (audio lecture, online), but they often cannot use the potential (project a table or presentation).

6. I am not motivated enough, especially in the courses without exercising finished only by a final test - nothing motivates me to work systematically, I have problems to make myself study at home.

7. Online teaching is very practical for some courses, especially lectures; exercising depends on teachers.

8. We miss lectures of experts and excursions.

9. It is difficult for me to concentrate in the process of online teaching, I need the straight interaction, and speaking in front of a camera is not satisfying.

10. A poor quality of connection, more time spent of learning.

What field of study would be more convenient for online teaching after the corona pandemic is over, what would not?

1. Online teaching could be effective for the courses related to history or economic and political development of states.

2. Such courses as mathematics, microeconomics and macroeconomics are not suitable; explanation of problems is important for them.

3. It would be convenient for students to record lectures and come back to them while revising the subject matter, respectively listen to them if someone could not be present at the lecture because of illness.

4. The next advantage of online teaching is a possibility of connecting to it from any place.

5. Tutorials of final works could be done online.

6. Online teaching is not sufficient for doing exercises.

7. Online lectures could be sufficient for the courses concerning the whole grade.

The next question was focused on the effect on the pandemic on the students' plan for the future. The structure of answers is presented by Fig. 3. The students' answers from both schools differed a lot. That is why we present them for each school separately.

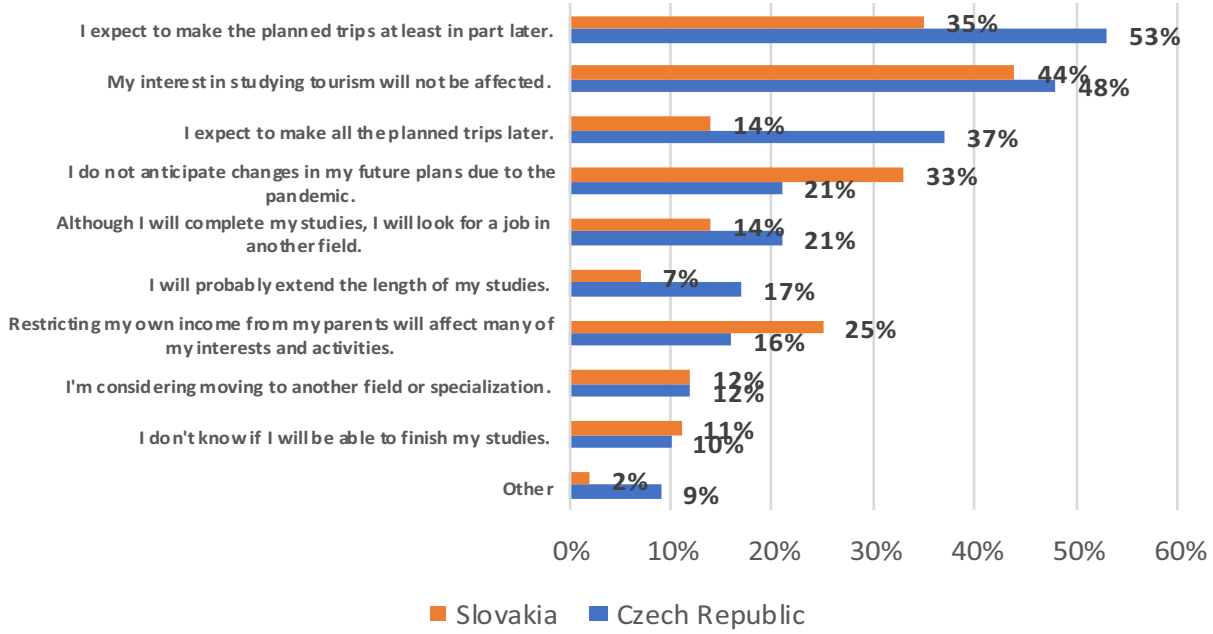

Fig. 3. How will the coronavirus pandemic affect your future plans? (\% positive answers) 
Half the students from Prague intend to make planned trips later. $37 \%$ of the students are going to realise all their trips. The students of Prešov University in Prešov make the proportion $35 \%$ and $14 \%$. The COVID-19 pandemic will not affect half the students of both schools in terms of going on their studies of tourism. One third of Prague students and onefifth of Prešov students will not be affected in terms of their plans for the future. One quarter of Slovak students and one sixth of Czech students are afraid of getting lower financial support from their parents. Graph 4 shows how the students see finding their place in tourism industry in the future. The students that do not see such perspective think that they might start their own business or work in some other fields, e. g. IT or education system.

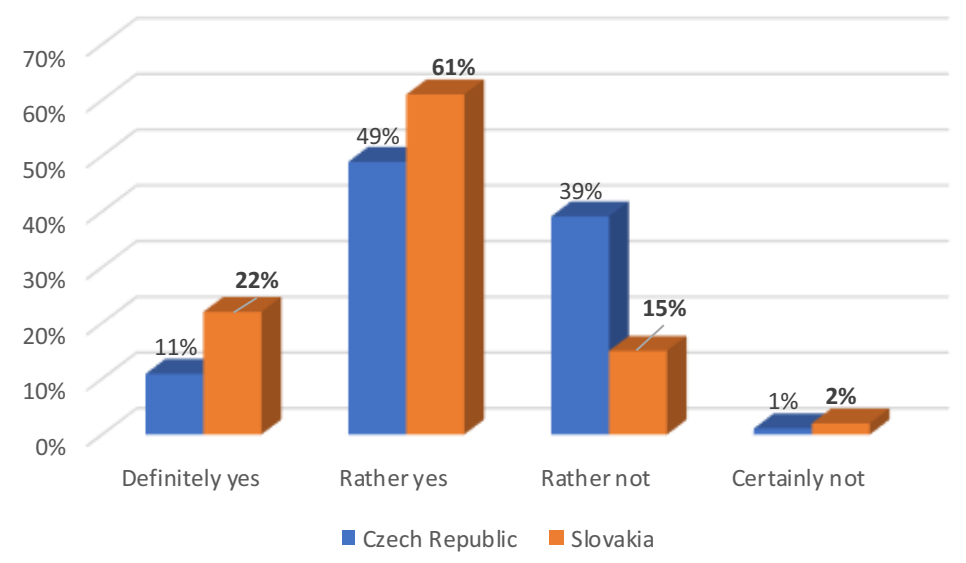

Fig. 4. How students see their future career in tourism (proportion of positive answers)

\subsection{Students' opinions on the further development of tourism at home and in the world}

Fig. 5 presents students' opinions on their future job in tourism industry. Similar opinion of the students of both schools had been given. Almost $50 \%$ of the students think that there will be a decline in employment but later it will rise up to the pre-pandemic level. The same number of students are afraid that higher unemployment will last longer.

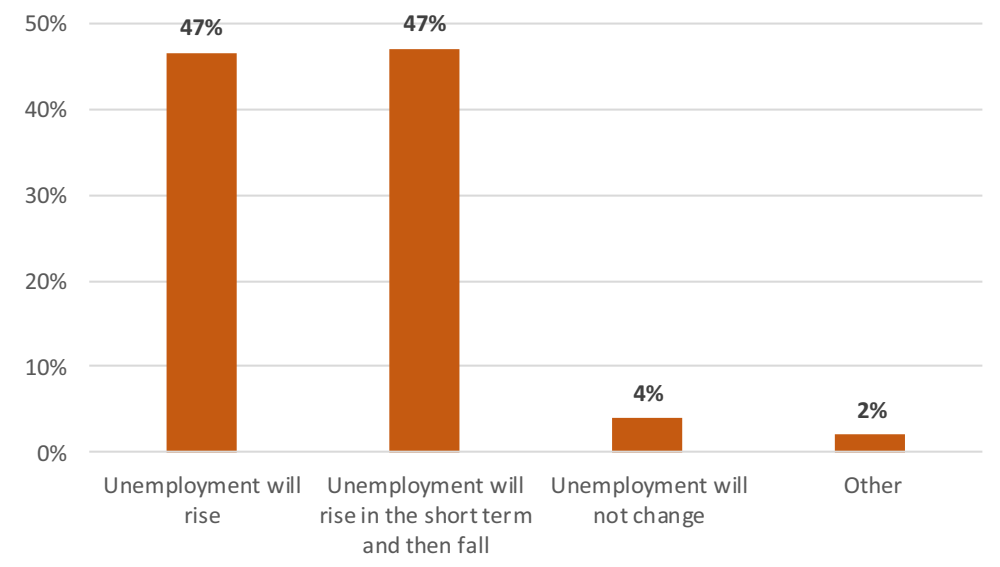

Fig. 5. The impact of the coronavirus pandemic on employment in tourism (\% positive answers) 
Opinions of Czech and Slovak students on development of tourism in 2020 did not differ much (Fig. 6). 9 out of 10 Czech students think that home tourism will increase. The proportion of Slovak students is 8 out of 10 . The students could also asses changes in percentage. Average percentage of their assessment was $43 \%$, but with wide range. The highest difference of their assessment was in incoming. The fall in case of the Czech students was $77 \%$, the Slovak students - only $24 \%$. Average assessment of incoming was $58 \%$. Approximately one-fifth of the students assume that, on the contrary, domestic tourism will fall by $20 \%$. Students of both schools expect a large fall of outgoing. Average of students' assessment make $52 \%$ which means that residents travel abroad will fall by $50 \%$.

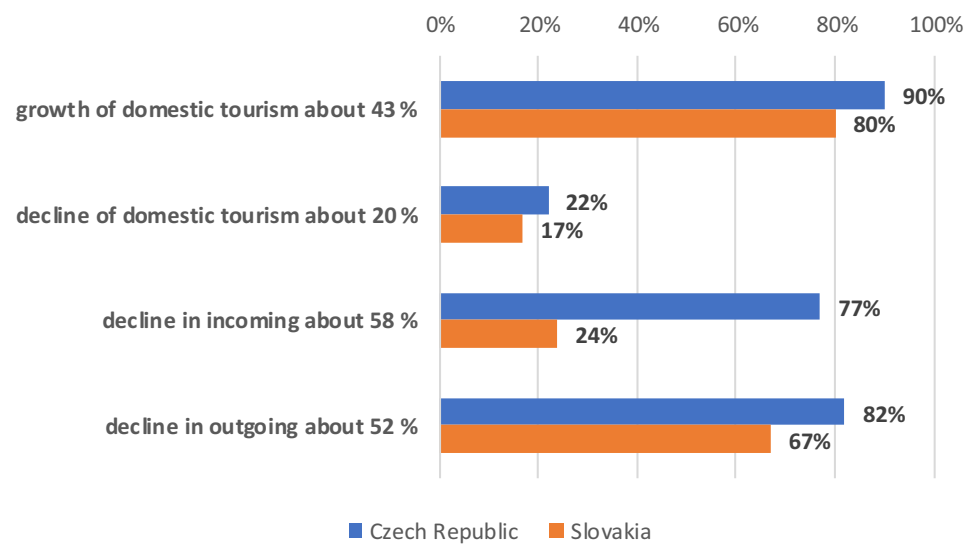

Fig. 6. Development of tourism this year (proportion of positive answers)

Czech students are much more pessimistic than Slovak students about development of tourism in the next two years. 7 out of 10 Czech students think that domestic tourism will grow in the next years. The proportion of Slovak students is 9 out of 10 . The average growth rating is $22 \%$.Vice versa, one quarter of the Czech students suppose that domestic tourism will decline by $25 \%$ in the next years. Every tenth Slovak student expects decline of domestic tourism. Students are sceptical in terms of the future development of outgoing and incoming. $59 \%$ of the Czech students think that incoming will fall by $26 \%$ and outgoing by $33 \%$. The Slovak students assume that outgoing will decline by $28 \%$ and incoming by $11 \%$.

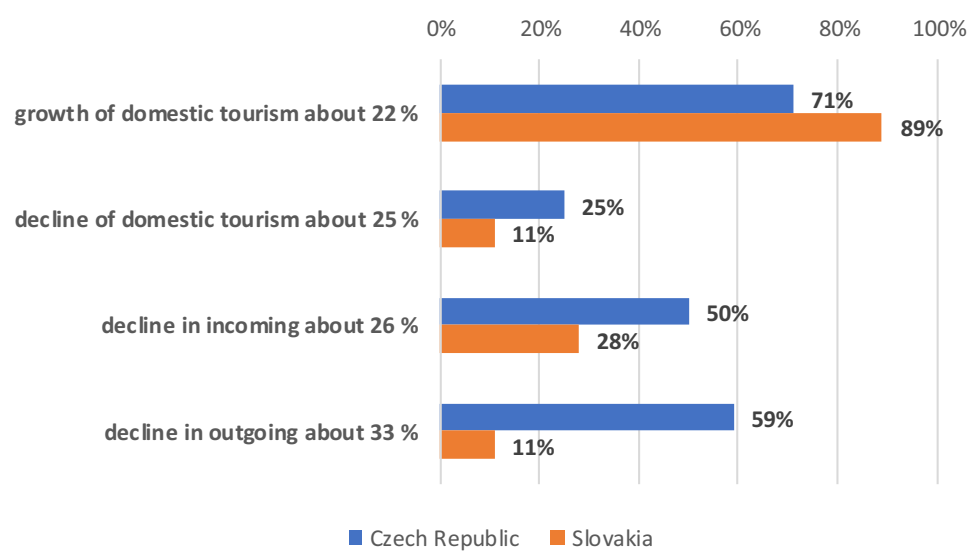

Fig. 7. Development of tourism in the next few years (proportion of positive answers) 
Identical questions concerning development of tourism in the world were asked. Table 1 presents the structure of answers. Majority of the students expect faster development of tourism in the Czech Republic and in Slovakia than average growth in other states. Greater part of the students assume that decline of tourism in the world will be higher than in the Czech and Slovak Republics.

Table 1. Changes in tourism in the world (proportion of positive answers)

\begin{tabular}{|l|r|r|r|r|}
\hline \multirow{2}{*}{} & \multicolumn{2}{|c|}{ This year (2020) } & \multicolumn{2}{c|}{ In the next few years } \\
\cline { 2 - 5 } & Czechia & Slovakia & Czechia & \multicolumn{1}{|c|}{ Slovakia } \\
\hline Growth of domestic tourism & $80 \%$ & $82 \%$ & $67 \%$ & $94 \%$ \\
\hline Decline of domestic tourism & $20 \%$ & $18 \%$ & $33 \%$ & $6 \%$ \\
\hline Decline in incoming & $72 \%$ & $32 \%$ & $50 \%$ & $39 \%$ \\
\hline Decline in outgoing & $72 \%$ & $58 \%$ & $72 \%$ & $61 \%$ \\
\hline
\end{tabular}

\section{Conclusions}

The results of the implemented research brought interesting findings about perception of online teaching by the students and their opinions of the future development of tourism in the Czech Republic, in Slovakia and in the world. The accomplished research of the students' opinions on online teaching and perspectives of their work in tourism emerge the fact that 50 $\%$ of the students lost their jobs, which they were doing in addition to their studies. One third of the students canceled their trips abroad. One quarter of them canceled their trip in the home country, one-fifth of the students underwent the quarantine and every fourteenth student did a volunteer work concerning the pandemic. $55 \%$ of the students would welcome wider range of online teaching after the pandemic is over. On the contrary, $45 \%$ reject online teaching. $90 \%$ of the students from Prague and $50 \%$ from Prešov guess they will make a part or all the planned trips later. The COVID-19 pandemic will not affect the students' intention to study tourism. One third of the Czech students and one-fifth of the Slovak students will not change their plans for the future. One quarter of the Slovak students and one sixth of the Czech students are afraid of lower financial support from their parents. $83 \%$ of the Slovak students have a positive view on their activity in tourism but only $60 \%$ of the Czech students think positively. The students that do not see their perspective positively think they will start their own business or will find job in the IT sector or education system. As for development of tourism at home and in the world, $50 \%$ of the students assume that there will be decrease of employment in tourism only temporarily, later employment will increased to the level before the pandemic. The same number of students are afraid that increased unemployment in tourism will last longer. $90 \%$ of the Czech students and $80 \%$ of the Slovak students assume that because of the COVID-19 pandemic domestic tourism will increase by $43 \%$. The highest difference in opinions is in decreasing incoming this year. $77 \%$ of the Czech students predict the fall, only $24 \%$ of the Slovak student do so. The students of both schools expect $50 \%$ decrease of travelling abroad. The Czech students are evidently much more pessimistic about development of tourism than the Slovak students are. Only 7 out of 10 Czech students think that domestic tourism will grow in the next few years. The proportion of the Slovak students is 9 out of 10 . Expected average increase is by $22 \%$. On the contrary, one quarter of the Czech students and one tenth of the Slovak students think that decrease of domestic tourism will make $25 \%$ in the years to come. The Czech students are pessimistic mainly about future development of outgoing. According to the opinions of the students involved in the research, domestic tourism will grow faster in the Czech lands and in Slovakia than presumed average of increase in other countries. Greater part of the students think that decrease of international tourism will be higher than in the Czech and Slovak Republics. There are certain limitations that exist in the interpretation of results, for example, the 
research sample is represented by students from one university in Slovakia and one from the Czech Republic. This means that the results can be generalized only for the needs of this article, however in case of wanting to obtain objective results on the international level, it is necessary to conduct a similar survey at other universities across Slovakia and the Czech Republic. Another dimension for research is cooperation with universities with similar field of study in both countries and comparison of the received results. The results could be used for a more specific survey, which would take into account the conclusions of a possible comparison of results at the level of university students in Slovakia and the Czech Republic (or university students studying within the economic field).

\section{References}

1. Donthu, N., Gustafsson, A. (2020). Effects of COVID-19 on business and research. Journal of Business Research, 117, 284-289.

2. Bapuji, H., Patel, Ch., Ertug, G. (2020). Corona Crisis and Inequality: Why Management Research Needs a Societal Turn. Journal of Management, 46(7), 1205-1222.

3. Stalenis, G., Hodgson, A., Boumphrey, S. (2020, April). Passport - The Impact of Coronavirus on the Global Economy. Euromonitor International.

4. Zenker, S., Kock, F. (2020). The coronavirus pandemic - a critical discussion of a tourism research agenda. Tourism Management, 81, Art. No. 104164.

5. UNWTO. (2020, March 13). News release - New Data Shows Tourism and COVID-19. Retrieved from: https://www.unwto.org/international-tourism-and-covid-19

6. Farzanegan, M.R., Gholipour, H.F., Feizi, M., Nunkoo, R, Andargoli, A.E. (2020). International Tourism and Outbreak of Coronavirus (COVID-19): A Cross-Country Analysis. Journal of Travel Research, Art. No. 0047287520931593.

7. UNWTO. (2020, June 22). News release - New Data Shows Impact of COVID-19 on Tourism as UNWTO Calls for Responsible Restart of the Sector. Retrieved from: https://webunwto.s3.eu-west-1.amazonaws.com/s3fs-public/2020-06/200622Barometer-June-EN.pdf

8. UNWTO. (2020, May). UNWTO World Tourism Barometer May 2020 - Special focus on the Impact of COVID-19. UNWTO.

9. Kyte, S. (2020, April 01) Travel \& Tourism | Europe-Updated Coronavirus impacts and the path to recovery. Retrieved from: Tourism Economics. Oxford. $\mathrm{http}$ ://resources.oxfordeconomics.com/travel-tourism-europe-updated-coronavirusimpacts-and-the-path-to-recovery

10. Gőssling, S., Scott, D., Hall, C. M. (2020). Pandemics, tourism and global change: a rapid assessment of COVID-19. Journal of Sustainable Tourism, 29(1), 1-20.

11. Český statistický úřad. (2020, July 27). Cestovní ruch - 1. čtvrtletí 2020. Retrieved from: https://www.czso.cz/csu/czso/cri/cestovni-ruch-1-ctvrtleti-2020

12. Štatistický úrad SR. (2020, July 27). Vývoj cestovného ruchu v ubytovacích zariadeniach SR v apríli 2020. Retrieved from: https://slovak.statistics.sk/

13. Quacquarelli Symonds. (2020, July). The Impact of the Coronavirus on Global Higher Education. Retrieved from: http://info.qs.com/rs/335-VIN-535/images/The-Impact-ofthe-Coronavirus-on-Glogal-Higher-Education.pdf

14. European Students' Union. (2020). COVID-19 Position Paper-A multidimensional crisis that affects us all. Retrieved from: https://www.esu-online.org/?policy=covid-19position-paper-a-multidimensional-crisis-that-affects-us-all 
15. Bryson, J.R., Andres, L. (2020). Covid-19 and rapid adoption and improvisation of online teaching: curating resources for extensive versus intensive online learning experiences. Journal of Geography in Higher Education, 44(4), 608-623.

16. Rusu, O. (2020, July 27). International Student Plans - Impact of COVID-19. Retrieved from: https://studyportals.com/intelligence/international-student-plans-impact-ofcovid-19/

17. Marinoni, G., Land, H., Jensen, T. (2020, July 27). The Impact of COVID-19 on Higher Education around the World. International Association of Universities. Retrieved from: https://www.iau-aiu.net/IMG/pdf/iau_covid19_and_he_survey_report_final_may_ 2020.pdf

18. Scull, J., Phillips, M., Sharma, U., Garnier, K. (2020). Innovations in teacher education at the time of COVID19: an Austalian perspective. Journal of education for teaching, Early Access: August 2020.

19. Allen, J., Rowan, L., Singh, P. (2020). Teaching and teacher education in the time of COVID-19. Asia-Pacific Journal of Teacher Education, 48(3), 233-236.

20. König, J., Jäger-Biela, D., Glutsch, N. (2020). Adapting to online teaching during COVID-19 school closure : teacher education and teacher competence effects among early career teachers in Germany. European Journal of Teacher Education, 43(4), 608622.

21. Buitendijk S, Ward H., Shimshon G., et al. (2020). COVID-19 : an opportunity to rethink global cooperation in higher education and research. BMJ Global Health, 5, Art. No. 002790.

22. Watermeyer, R., Crick, T., Knight, C., Goodall, J. (2020). COVID-19 and digital disruption in UK universities: afflictions and affordances of emergency online migration. Higher Education, Early Access: June 2020. 